\title{
Implementation of Digital Literacy Through E-learning In Learning Process at Pesantren University
}

\author{
Rila Setyaningsih \\ Communication Department \\ University of Darussalam Gontor \\ Ponorogo, Indonesia \\ rilasetya@unida.gontor.ac.id
}

\author{
Abdullah \\ Communication Department \\ University of Darussalam Gontor \\ Ponorogo, Indonesia \\ abdullah@unida.gontor.ac.id
}

\author{
Edy Prihantoro \\ Communication Department \\ University of Gunadarma \\ Depok, Indonesia \\ edipri@staff.gunadarma.ac.id
}

\author{
Hustinawaty \\ Information Technology Department \\ University of Darussalam Gontor \\ Depok, Indonesia \\ hustina@staff.gunadarma.ac.id
}

\begin{abstract}
The purpose of this research is to know the digital literacy implementation model through the utilization of elearning in the learning process at a pesantren (boarding school) university. The method used in this research is qualitative. Data collection was done through observation and interviews with lecturers of five basic subjects (Introduction to Communication Studies, Communication Theory, Communication Psychology, Contextual Communication and Mass Communication) in the Communication Studies Program at the University of Darussalam Gontor. The result of this research is a digital literacy implementation model through e-learning utilization in the learning process at pesantren university. The contribution of this research is a digital literacy implementation model through e-learning utilization in the learning process at a pesantren university.
\end{abstract}

Keywords_- digital literacy; e-learning; pesantren university

\section{INTRODUCTION}

The rapid flow of information and the emergence of globalization resulted in a transformation process that was characterized by a set of social and cultural changes in society, as well as in the education world. Learning activities have changed significantly with the emergence of digitalization due to technological advances. The learning processes at some of the previous education institutions are limited to textual book use. However, it now adapted to the contextual learning model through the use of digital media in the learning process.
The emergence of digitalization in the education world makes it easy for everyone to obtain reference materials through search engines. It can be done at a low cost, in an easy way and in real time. Lau states "people can easily quite literally at their fingertips via internet with only a few minutes of search time on the computer with a click of a mouse.” [1]. This shows that technological developments have resulted in the world not having spacing and time. Friedman describes it as "the world is flat". [2].

Advances in information technology is creating opportunities as well as challenges in the education world as well as in pesantren universities. Pesantren educational institutions that have already for a long time applied the textual education model for studying the books (kitab) are now facing new challenges with the advent of technological developments. This condition requires the pesantren educational institution, especially pesantren universities, to adjust. This is a demand of 21st century education that aims to encourage learners to master 21st century skills so as to be more responsive to the era developing and changing. According to the documents set by EnGauge 21st Century Skills, one of the most important domains of 21st century education is "Digital-Age Literacy" [3]. Digital-age in the education world, especially in higher education, has consequences in the form of learning design by utilizing digital media as a means to increase student knowledge. Pesantren universities as part of higher education 
institutions should adjust themselves to organize digital-based learning process.

Trilling \& Fadel said that in the 21st century the education must always move in line with the progress of the era [4]. This movement is based on a paradigm shift from conventional education to modern-era education. The paradigm shift in education can be seen in table 1 .

TABLE I. DIFFERENCES PARADIGM OF OLD EDUCATION AND EDUCATION IN 21ST CENTURY

\begin{tabular}{|l|l|}
\hline \multicolumn{1}{|c|}{ Old Paradigm } & \multicolumn{1}{c|}{ The 21st Century Paradigm } \\
\hline Teacher centered & Student centered \\
\hline Direct teaching & Interactive teaching \\
\hline Knowledge & Skills \\
\hline Material & Process \\
\hline Basic skills & Applied skills \\
\hline Facts and principles & Questions and problems \\
\hline Theory & Practice \\
\hline Material-based & Project-based \\
\hline Time-limited & According to the needs \\
\hline Competitive & Collaborative \\
\hline One-size-fits-all & Personalized \\
\hline Focused on the class & Focused on the global community \\
\hline Text-based & Web-based \\
\hline Summative test & Formative evaluation \\
\hline Learning to continue study & Learning for life \\
\hline & (Source: Trilling \& Fadel, 2009) \\
\hline
\end{tabular}

Table 1 shows the importance of a concept and mechanism of learning based on information technology which became known as e-learning. This has led to the transformation of conventional education into digital form.

Utilization of e-learning in the world of education as well as pesantren universities has become a demand in the digital era today. There are several studies that have been done with a focus of e-learning utilization in the learning process. In 2013, Agustina conducted a research entitled "Utilization of Elearning as a Learning Media". The study was conducted with the aim of finding out the benefits of e-learning in the learning process and factors that have an influence at Bina Darma University in Palembang. The results showed that e-learning utilization condition as a learning medium at Bina Darma University was in good condition with a percentage level of $60 \%$ [5].

Another study was conducted by Barokati and Annas in 2013 under the title "Development of Learning Based on Blended Learning in Computer Programming Course (Case Study: UNISDA Lamongan)". In this research, Computer Programming courses become one of the first tests in elearning implementation. The results show that in a Computer Programming Course that has been applied in UNISDA there are some better differences when compared with before the implementation of e-learning [6].

Both studies show that the utilization of e-learning becomes an important thing that needs to be done in university to keep up with the development of information technology. Utilization of e-learning is one form of implementation of digital literacy in pesantren universities. Digital literacy conducted by university is a form of communication and collaboration, i.e. active participation in digital network for learning and research. The focus in this paper discusses the implementation of digital literacy through the utilization of elearning in Communication Studies Program UNIDA Gontor (University of Darussalam Gontor). UNIDA Gontor University as one of the largest pesantren universities in East Java seeks to adapt in utilizing e-learning as an effort to implement digital literacy. The use of e-learning is done by developing learning content on the basic subjects (Introduction to Communication Studies, Communication Theory, Communication Psychology, Contextual Communication, and Mass Communication) in Communication Studies Program, University of Darussalam Gontor.

NCREL \& Metiri Group, in EnGauge 21st Century Skills in the 21st century, said that literacy skills are not limited to literacy, listening, writing and speaking, but more than that, on literacy capabilities that are connected to each other in the digital era as it is today. Digital literacy, also known as computer literacy, is a proficiency in the use of computers, the Internet, and other digital equipment [1]. Digital literature refers to the effort to recognize, seek, understand, recognize and analyze and use digital technology.

Information technology is one form of digital media. Besides bringing negative impacts, the existence of digital media can also lead to negative things. This condition then gave birth to a thought about the importance of digital literacy through the utilization of e-learning. In this study, the definition of digital literacy is adopted from the widely used definition of media literacy from Livingstone in the article "What Is Media Literacy?” which defines media literacy as "the ability to access, analyze, evaluate and create messages in various contexts" [7]. According to Sholihah, digital literacy is an attempt to find, use and disseminate information effectively [8]. Thus, digital literacy is the basic ability used to understand digital media from various aspects of its use to the message presented.

In this study, digital literacy means the ability to access, use, and disseminate information effectively in the context of learning basic courses in Communication Studies Program UNIDA Gontor. The purpose of this research is to study the digital literacy implementation model through e-learning utilization at the University of Darussalam Gontor.

\section{RESEARCH METHOD}

This research uses a qualitative method to explore the effort that has been done by pesantren universities, in this case the University of Darussalam Gontor, in implementing digital literacy through e-learning utilization. The data in this research was obtained through direct observation and in-depth interviews. The observation was conducted in the Communication Studies Program of the University of Darussalam Gontor as the place for the e-learning development. Interviews were conducted with lecturers in Communication Studies Program UNIDA Gontor as research subjects. The number of research subjects consisted of 5 
subjects of basic subjects, i.e. Introduction to Communication Studies, Communication Theory, Communication Psychology, Contextual Communication, and Mass Communication. After conducting observations and in-depth interviews, the researcher then constructed the messages that were obtained from the informants. After exploring the utilization of elearning in the learning process conducted by the lecturers Science Communication Study Program UNIDA Gontor, researchers then mapped the use of e-learning as a form of digital literacy implementation consisting of access, using skill, and communicative abilities in the learning process conducted by five lecturers of Communication Studies Program University of Darussalam Gontor as a research subject.

\section{RESEARCH RESULT}

Research titled "Implementation of Digital Literacy Through E-Learning Utilization in Learning Process at Pesantren University" is the result of research conducted by using qualitative methods with a natural background as a whole. Researchers conducted direct observation and in-depth interviews with the subject of the study. Researchers make direct observations by viewing and observing teaching content uploaded training activities conducted by lecturers who teach basic courses in the Communication Studies Program. From the observations made by researchers, it was found that during this learning activities conducted by lecturers in the Communication Science Study Program UNIDA Gontor already utilizes digital media, but it is not yet maximal. Utilization of e-learning in the learning process is one form of implementation of digital literacy at University of Darussalam Gontor as a pesantren based university.

Digital literacy is an individual's interest, attitude and ability to use digital technology and communication tools to access, manage, integrate, analyze and evaluate information, build new knowledge, create and communicate with others in order to participate effectively in society. According to Sholihah, digital literacy is an attempt to find, use and disseminate information effectively [8]. Digital media is one of the gadgets in new media. There are four main categories, namely: 1). Interpersonal communication media such as email, 2). Interactive game media such as games, 3). Media search information such as search engines on the Net, and 4). Participatory media, like chatrooms on the Net. In this study, digital literacy is the ability to access, use and disseminate information effectively. The information in question is in the form of lecture materials, discussion forums, and quiz / practice questions.

To know the ability to use and utilize e-learning by lecturer of Communication Science Study Program UNIDA Gontor, in this research it will be studied based on Livingstone's media literacy criteria which have been adopted and adapted into digital media in the form of an e-learning portal. The criteria consist of three components, namely access, using skill, and communicative abilities. First, access can be interpreted as the ability of the audience in searching, obtaining, and collecting information [9]. Access is defined both as physical access and the ability to use various forms of media. In this study, it referred to the ability of research subjects in using e-learning in the learning process.
Accessing e-learning nowadays is no longer as an obstacle for the lecturers of Communication Studies Program University of Darussalam Gontor. This is because current media access can be done anywhere and anytime. UNIDA Gontor has provided free Wi-Fi in all public areas in the campus environment that can be reached by the entire academic community, especially lecturers, 24 hours a day. In addition, elearning accessibility can also be found with the application of Moodle that has been installed in the lecturers' mobile phones of the Communication Studies Program UNIDA Gontor, so that e-learning can really be conducted anytime and anywhere. Based on the interview result, there were no significant obstacles related to e-learning access in the learning process.

The second component of digital literacy in this research is using skill, which is the ability to operate the media [10]. Use skills include several criteria, namely the ability to use media (media skills), the ability to use the media actively (balanced and active use of media), and the ability to use and the utilization of media at a high level (advanced media use). In this study, the ability of research subjects in operating elearning as well as utilizing the existing content in the elearning portal was studied.

Based on the results of the research note that the subject of research, i.e. lecturers of the Communication Studies program in University of Darussalam Gontor, have been able to use and utilize e-learning in the learning process. E-learning is a learning medium that is able to accommodate the concept of virtual learning in full. In e-learning developed in Communication Studies Program UNIDA Gontor there is material content, forums as a medium of discussion between lecturers with the students, and also the quiz / question exercise. With the e-learning, lecturers learning materials can be better documented. E-learning will greatly improve the use of digital literacy skills of the lecturers because the learning activities can be done virtually without having to meet face to face in the classroom.

The third component besides access and using skill is communicative abilities, i.e. communication skills and participation through media [10]. Communicative abilities include the ability to build social relationships and participate in the community through the media. In addition, these communicative abilities also include the ability to create and produce media content. The communicative abilities indicator consists of information updates and discussions through forums in e-learning.

Based on the result of research, it is found that before using and utilizing e-learning, the ability of communicative abilities in the learning process cannot be done. The ability of communication on the internet is limited to the status update activity in social media that has nothing to do with the learning process, doing social media criticism outside the learning materials, as well as news updates from the internet for the benefit of increased information for themselves. Therefore, it can be said before the existence of e-learning, communicative abilities research subjects in the learning process is still quite low. With e-learning as a virtual learning media the ability of research subjects in the criteria of communicative abilities will 
certainly increase. This is because learning activities will always use and utilize the internet.

\section{CONCLUSION}

From the analysis and discussion, it can be concluded that the digital literacy implementation model in pesantren universities, in this case University of Darussalam Gontor, is conducted through the utilization of e-learning in the process of basic courses learning. The digital literacy component consists of three things: access, using skill, and communicative abilities.

\section{ACKNOWLEDGMENT}

The author would like to thank the Ministry of Research, Technology and Higher Education, Director General of Development and Research Enhancement of the Republic of Indonesia.

\section{REFERENCES}

[1] Afandi, T. Junanto, and R. Afriani, "Implementasi digital age literacy dalam pendidikan abad 21 di Indonesia [Digital age literacy implementation in Indonesia's 21st century education," in Prosiding Seminar Nasional Pendidikan Sains, Surakarta, 2016, pp. 113.

[2] T.L Friedman, The world is flat 3.0: A brief history of the twenty first century, New York: Picador, 2007.
[3] NCREL \& Metiri Group, EnGauge 21st century skills: digital literacy for digital age. Napierville, IL and Los Angeles, CA: NCREL and Metiri, 2003.

[4] B. Trilling and Fadel, C, 21st Century skills: learning for life in our times. San Fransisco: Josey-Bass, 2009.

[5] M. Agustina, "Pemanfaatan e-learning sebagai media pembelajaran [Utilization of e-learning as learning media]," in Prosiding Seminar Nasional Aplikasi Teknologi Informasi, ISSN: 1907-5022, Yogyakarta, Juni 2013, pp.8-12.

[6] N. Barokati and F. Annas, "Pengembangan pembelajaran berbasis blended learning pada mata kuliah pemrograman komputer (studi kasus UNISDA Lamongan)[Learning development based on blended learning on computer programming course (case study of UNISDA Lamongan)]”, Jurnal SISFO, vol.7 no.2, eISSN: 2301- 4273, 2013.

[7] S. Livingstone, What is media literacy?, Intermedia, 2004, pp.18-20.

[8] K. Sholihah, “Analisis literasi digital: studi pemanfaatan jurnal elektronik oleh mahasiswa magister manajemen di perpustakaan UKSW Salatiga [Digital literacy analysis: study of electronic journal utilization by master of management students at the library of Satya Wacana Christian University Salatiga],” M.I.I.P Thesis, Dept. Of Postgrad. Stud. Sunan Kalijaga State Islamic Univ., Yogyakarta, Indonesia, 2016, pp.5.

[9] I. Fitriyarini, "Literasi media pada mahasiswa prodi lmu komunikasi Universitas Mulawarman [Media literacy on Communication Studies study program of Mulawarman University],” J. Komun., vol.8, no.1, pp. 51-67, 2016.

[10] European Commission, Study on assessment criteria for media literacy levels, Brussels, 2009. 